\title{
Did Weber have an adequate theory of nationalism? How did his theoretical understanding of nationalism relate to his own passionate German nationalism?*
}

\author{
Nicolas Fleet**
}

\begin{abstract}
Resumen
Se propone una estrategia conceptual para vincular la teoría con la política del nacionalismo de Max Weber. La argumentación se orienta a rescatar la coherencia entre el escaso trabajo teórico que Weber publicó sobre nación y nacionalismo, con el rol prolífico que él tuvo como intelectual y político del nacionalismo alemán antes y después de la Primera Guerra Mundial. De manera general, la nación se constituye como fenómeno sociológico en el ámbito de los valores, y su efectividad depende de la acción nacionalista dirigida a consolidar y movilizar la solidaridad del grupo a través del prestigio y el poder. Se plantea la distinción entre "nación en sí", como un proceso espontáneo de diferenciación intersubjetiva del grupo -fuera de toda consideración objetiva o racial en la teoría de Weber-, y "nación para sí", como la acción colectiva de consolidación de su identidad en términos de homogeneidad interna y diferenciación externa (oposición a otras naciones), a través del rol de los intelectuales en la difusión del prestigio del grupo y la vocación por el poder político (Estado) -donde se posicionan los argumentos nacionalistas de Weber-. Finalmente, temas fundamentales de la sociología de Weber, como la ética de la acción política, la legitimidad de la dominación estatal y la modernización social, son reinterpretados en un sentido instrumental, como medios de los fines de su nacionalismo práctico.
\end{abstract}

Palabras clave: Max Weber - nación - nacionalismo - acción colectiva - Estado - teoría sociológica.

\begin{abstract}
A conceptual strategy is proposed in order to link Max Weber's theory and politics of nationalism. The argument is oriented to rescue the coherence between the scarce theoretical work published by Weber on nation and nationalism, with the prolific role he had as intellectual and militant of German nationalism before and after the First World War. Broadly, nation constitutes itself as a sociological phenomenon in the realm of values, and its effectiveness depends on the nationalist action toward the consolidation and mobilization of the group solidarity through prestige and power. Consequently, a distinction is introduced between "nation in itself", as an spontaneous process of inter-subjective differentiation of the group -regardless of any objective or racial argument according to Weber's theory- and "nation for itself", as the collective action of consolidation of its identity in terms of internal homogeneity and external differentiation (opposition to other nations), through the role of intellectuals in the diffusion of the prestige of the group, and the vocation for political power (state) -where the arguments of Weber nationalism dwell-. Finally, key subjects of Weber's sociology, as the ethics of political action, the legitimacy of state domination, and social modernization, are reinterpreted in an instrumental sense, as means for the ends of his practical nationalism.
\end{abstract}

Keywords: Max Weber - nation - nationalism - collective action - state - sociological theory.

* El autor agradece los comentarios y aportes del Dr. John Breuilly (London School of Economics) y el Dr. Gero Lenhardt (Institut für Hochschulforschung Halle Wittenberg). No obstante, ellos no son responsables por los errores y omisiones que este artículo pueda presentar.

** Sociólogo, Universidad de Chile. MSc in Political Sociology, London School of Economics and Political Science. $\mathrm{PhD} \odot$, University of Cambridge. 


\section{INTRODUCTION}

In order to answer the questions above, this essay will propose an integrated approach to Max Weber's theory of nation and his practical nationalism. The relation between nation and nationalism takes here the form of a specific link between solidarity of the group and collective action; or, in other words, between common values and power. Thereby, I will try to sociologically deal with the gap which remains between the concept of nation and the plea of nationalism. Weber himself dedicated very few pages of "Economy and Society" to theoretically discuss the concepts nation and nationalism. Perhaps, this is why persists the idea that Weber divorced the study of nation as an object from the advocacy of nation as a political end. Thus, my aim in this essay is to try to dilute such distinction between the theoretical and political approach to the phenomenon of nation in Weber's work.

Despite that Weber has many more writings where an explicit advocacy towards nationalism is to be found, than those where he tried to construct a consistent perspective about the nation, these two poles, nation and nationalism, can be articulated, through Weber's work, as a continuum. This means that there is not such a distinction between the two faces of Max Weber: the cool scholar and the passionate nationalist, and that his theoretical analyzes and political orientations fit in the classical differentiation between facts and values. Moreover, Weber's somehow shifting nationalist appeals were not the expression of a sort of theoretical and political irregularity, neither can provide us a standpoint to neglect Weber's nationalism as a misconception from part of "weberologists" 1 , but they rather express practical adjustments regarding the position of Germany in the balance of world powers before and after the First World War. After all, the main concern of Weber's nationalism was how best to preserve German national particularities, according to the political conditions of her immediate internal and external environment.

For Weber the "nation" belongs to the realm of values, corresponding to a unique articulation of collective experiences and meanings that, seen as a movement, tends to increase the internal assimilation of its members and the external differentiation from the other nations, "(...) which started from small difference that were them cultivated and intensified" (Weber, [1921] 1968: 388). Thus, "nationalism" is nothing other than the action that puts this "movement" in motion. The presumed identity of the national community becomes a concrete form of collective action, a political reality that claims the monopolistic closure of the group based in prestige orientations. In this sense, the particular collective action of nationalism mobilizes the specificities brought about by the idea of nation and, in its typical form, implies the invocation of an autonomous polity. Now, to answer the question whether Weber had an adequate theory of nationalism it is required to move forward the analysis into the symbolic construction of the nation and its claims for power and self conservation both in the domestic and international scenario.

1 This seems to be the perspective of Kari Palonen (2001). 


\section{NATION IN ITSELF / NATION FOR ITSELF}

The Marxian construct of class in itself / class for itself ${ }^{2}$ could be usefully translated to this topic, with the purpose of understanding how nation, which refers to the solidarity of the members of a given community, becomes the basis and the motive of nationalist collective action. Class, in the same way as nation, has the quality of being constructed in a dialectical process of differentiation and opposition ${ }^{3}$.

On one hand, the process of differentiation of the "nation in itself" comes from the constitution of groups according to common language, religion and customs, which take the expression of a particular lifestyle. Weber underlined that this process of differentiation corresponds to a subjective level, and not to an objective one (here lies the major difference with the Marxian model of class in itself constructed around objective conditions of life). Thus, Weber refused to acknowledge arguments about the existence of nations based on scientific assumptions in relation to race, most probably not because of a normative outlook that disregards racist explanations, but because of its vagueness and lack of rigour. Still, the main point here is that such process of differentiation takes places in a spontaneous way, without the mediation of any kind of political will. On the other hand, the process of opposition, which we can think as "nation for itself", describes the constitution of a political power that assures the homogeneity of the internal conditions of the nation-state and the political community, and preserves the identity of the group against the aggressions of other nation-states. Hence, the state represents both the promotion (in the internal front) and the protection (in the external front) of the nation. It is important to say that, according to Weber, the state was not always regarded as an indispensable institution in the constitution of nation. Nevertheless, taking into account the circumstances of Germany of his time (before and after the First World War), the political autonomy guaranteed by state power was a precondition of national groupings. Before then were just "unpolitical" times.

The nation has been deconstructed into two levels, the first one is the "nation in itself", which corresponds to the level of solidarity of the group, and the second one is the "nation for itself", corresponding to the level of collective action: nationalism. What happens in between these two levels of the nation? In the same way as class constitution, it is the collective consciousness what determines the transition from "nation in itself" towards "nation for itself". At this point of the analysis it is not important to find out whether this consciousness springs "from below", vis-à-vis the meaningful articulation of the material and ideal interests of the community, or if it is manipulated "from above", in terms of the institutionalized political interests of the state. In fact, the distinction between "genuine" and "artificial" nation is pointless, since the shift from "nation in itself" towards "nation for itself" typically entails the mobilization of national consciousness into a political (i.e. instrumental) nationalist action undertaken through the state. In Weber's own words: "it is primarily the

2 This model can be found in Marx, Karl (1852): The Eighteen Brumaire of Louis Bonaparte and more specifically in Lukacs, Georg (1919): History and class consciousness.

3 This does not allow us to immediately re-elaborate Weber's thought in dialectical terms, albeit there have been accomplished attempts to do so, such as the case of the "Frankfurt School". 
political community, not matter how artificial organized, that inspires the belief in common ethnicity" ([1921] 1968: 389). Let us proceed in stages.

According to Weber, nation refers to a "community of memories". This quote on "ethnic groups" is suitable to the above proposed logic for the construction of national identity, as it follows:

"We shall call 'ethic groups' those human groups that entertain a subjective belief in their common descent because of similarities of physical type or of customs or both, or because of memories of colonization and migration; this belief must be important for the population of group formation; conversely, it does not matter whether or not an objective blood relationship exists" (Weber, [1921] 1968: 389).

And this other:

"Yet, above all, national solidarity may be linked to memories of a common political destiny with other nations" (Weber, 1946: 173).

Such memories develop a sense of particularity within the community: particular meaningful behaviour or particular life style. Whatever the emphasis on these two, the effect can be described as the particular allocation of values to social action (traditional action could be a paradigm in this case) capable to distinguish a group or society from others. Thus, language, the belief on a shared ethnicity (race) and customs are all expressions of this specific articulation of values that come from a holly past.

In the process of development of the "national consciousness", which defines the transition towards nation as collective action or, more specifically, "nationalism", there are two relevant elements to take into the account. Firstly, the role played by intellectuals as mediators in the movement from "nation in itself" to "nation for itself". This point is critical, as it has been discussed by scholars on Weber's political thought, because nationalism is not necessarily the proud possession of some primordial and native past, but rather something that nationalist intellectuals (such as the Grimm brothers) "introduce into the history books and create de novo in the consciousness of the nation" (Whimster, 1998: 70). This is related to the discussion above on the "artificial" character of the nation, condition which admittedly does not alter the process of consciousness formation but, more precisely, it facilitates. Furthermore, according to Beetham (1985), intellectuals are the bearers and the disseminators of national culture (kultur) into the masses. Secondly, nation building takes the form of a process of democratization, because of the participation of the masses into national culture. National language, the spreading of formal education and the creation of a pre-given understanding (i.e. common sense) through which any citizen is enabled to communicate with each other, are manifestations of this cultural democratization. The outcomes of this second effect are the homogenization of national values and the development of a sense of honour based in the membership to the nation. This latter is analogue to the process of formation of class consciousness according to the Marxian model. In Weber's language, "prestige" is a sentiment that steers the nation into nationalism and disposes the masses into claims for a common political destiny which, in turn, oppose them to other nations. Therefore, "prestige" serves 
as a link between the level of differentiation and the level of opposition. At the basis of actions oriented towards the attainment of national power, "prestige" constitutes the main motive, alongside a "(...) specific belief in responsibility towards succeeding generations" (Weber, 1946: 172). Moreover, according to Weber, prestige does not constitute a case of a particular ideology which remains in the superstructure of particular interests, since it builds the psychological foundations of the nation, which are "(...) shared even by the broad strata the economically subordinated classes" ${ }^{\prime 4}$.

"A nation is a community which normally tends to produce a state of its own" (Weber, 1946: 176). At this point, "nation" becomes a political concept because is directly related to the state. "Nation for itself" implies that national consciousness leads to collective action, in which political power (institutionalized and monopolized in the state) is at the service of the attainment of societal ends. In its pure form, Weber used the concept of "providential mission", as the belief which organizes the striving for power within the polity. The hypothesis is that such action is nationalist because in its ends it is actually value oriented towards the preservation of the national community, in the internal front, and to the achievement of political aims, in the external front. Of course, as Weber was decided to make clear to the political groupings of his time, particular interests of both the working class and bourgeoisie, such as the interests in the expansion of markets abroad to increase the level of wages and profits respectively, were aligned with national goals. In this sense: "no party, whatever its programme, can assume the effective direction of the state without becoming national" (Weber, [1917] 2003b: 106). Nationalism, in other words, constitutes a set of value orientations that provide the criteria to assess the quality and outcomes of political action. The following is an interesting quote from Weber's Freiburg Inaugural Lecture, which illustrates how particular interests have to be subordinated to national goals, according to his nationalist outlook:

"It is dangerous, and in the long term incompatible with the interests of the nation, for an economic declining class to exercise political rule (herrschaft). But is more dangerous still when classes which are moving towards economic power, and therefore expect to take over political rule, do not yet have the political maturity to assume the direction of the state." (Weber, [1895] 2003a: 21-22).

Consequent to the democratization process verified at the level of national culture, another process of democratization is required for the hegemony of national interests at the political level. This is the democratization that should be visible in the exercise of power and political decision making: admittedly, national culture can only survive under the protection of the state but, at the same time, the state needs a legitimatory input from nationalism, which is only consistent if the different strata of the political community are allowed to participate in the attainment of common goals. For Weber, nationalism consisted in a common ideal interest that goes beyond those of social classes and, therefore, it "offered a means of drawing the working class away form and attitude of total opposition to the existing social order" (Beetham, 1985: 144). Thus, in order to encourage the embracement of national goals from

4 Weber, Max: "Gesammelte politische schriften", pp. 18-19; taken from Beetham (1985: 120). 
the part of the working class, it was required convert their immediate resistance, derived from their subordinate position in the economic base, into consent and political participation. Equal suffrage appeared as a relevant path in order to attain that desired political solidarity. "Equal suffrage is a demand of national politics; it is not a party-political demand" (Weber, [1917] 2003b: 106). At the same time, Weber's nationalist outlook was the reason for his advocacy towards parliamentary politics as a fertile ground to produce national leadership. Also, parliamentary politics can be explained by its democratic merits.

\section{CONCLUSION: NATIONALISM, POLITICS AND MODERNIZATION}

Did Weber have an adequate theory of nationalism? His theory is consistent enough regarding that it derives directly from his reflections about the nature and dynamics of the national society. Nationalism refers to the meaning of collective action embedded in a national context. As it has been sustained, a nationalist action proceeds by strengthening the internal assimilation of the community and increasing the external differentiation. But it reaches its higher expression of self consciousness when, in a dialectical process, it mobilizes the whole community against another nations, that are actually seen as a menace to its own national preservation. At this level, "prestige" acts as the main motive of a collective nationalist action oriented towards political inclusion, leading to the institutionalization, in the internal front, of substantive forms of political membership, such as civil rights and welfare (Fleet, 2009), and to the legitimation, in the external front, of particular interests that foster a world policy through the state. Therefore, nation and nationalism refer both to social solidarity and social domination, rendering as a sociological construct that is aligned with the Weberian holistic view of society:

"(...) it may be suggested that for him (Weber) the conditions of solidarity on the basis of ideas or interests and the moral order of authority on the basis of a belief in legitimacy were the two perspectives through which a comprehensive view of society could be obtained" (Bendix, 1960: 291).

How did his theoretical understanding of nationalism relate to his own passionate German nationalism? Weber's concerns about the future of Germany were in direct relation with the capacity of the state, and the political forces responsible for its direction, to preserve national identity and national interests. It is false to contend that Weber was ambiguous and undecided in his practical recommendations about the Weltpolitik, because those stemmed from the changing political conditions of the correlation of forces in the

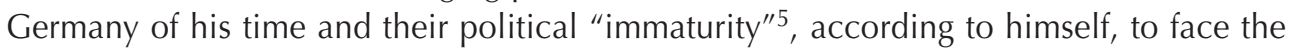
challenging international scenario. Those political conditions were especially different before and after the First World War.

For Weber, the state represented the political locus which had the power to consistently and permanently pursue national goals. In fact, the state had already taken a leading role in

5 Indeed, according to Giddens, Weber was precisely concerned with the political consciousness of the bourgeoisie as it was an "important underlying motive of the Protestant Ethic" (1972: 12). 
the construction of the nation "from above". So it was required that the political groupings assume the responsibility to lead the state according to the interests of Germany. A noteworthy Weberian political aspiration, as it was suggested in "Politics as Vocation" (1919), certainly was that the bourgeoisie and the proletariat would be able to articulate in a hegemonical power (Mommsen, 1990: 391), respectively constructed in terms of both (ethics of) responsibility and (ethics of) conviction, capable to define both German's domestic and world politics.

National interests demanded a more rational articulation of the political means of the state for the attainment of given national ends. Thus, Weber's invocations in the logic of the "nation for itself" were specific recommendations for the modernization of Germany's political and social institutions: the modernization of the party structure, the elections system, the economic policy, the constitution and so forth. Unsurprisingly, Weber had considerable influence on the American Functionalism's approach to modernization and social change. However, according to Weber's nationalist outlook, all of these measures were just means which usefulness depended of a decisive political leadership, based in national convictions and powerful enough to bring the values of the "nation in itself" into the power opportunities of the "nation for itself".

\section{REFERENCES}

Beetham, David (1985): Max Weber and the theory of modern politics, Polity Press, Cambridge.

Bendix, Reinhard (1960): Max Weber: an intellectual portrait, Heinemann, London.

Fleet, Nicolas (2009): "Razón y dominación. La legitimidad en Weber como referente de la acción política", Revista Austral de Ciencias Sociales, 16, pp. 21-36.

Giddens, Anthony (1972): Politics and sociology in the thought of Max Weber, The Macmillan Press Ltd., London and Basingstoke.

Lukács, Georg ([1919] 1971): History and class consciousness. Studies in Marxist dialectics, Merlin Press, London.

Marx, Karl ([1852] 1996): "The Eighteenth Brumaire of Louis Bonaparte", en Terrell Carver (ed.): Marx Later Political Writings, Cambridge University Press, Cambridge.

Mommsen, Wolfgang (1990): Max Weber and German politics 1890-1920, Chicago University Press, Chicago and London.

Palonen, Kari (2001): "Was Max Weber a 'nationalist'? A study in the rhetoric of conceptual change", Max Weber Studies, 1 (2), pp. 196-214.

Weber, Max (1946): From Max Weber: Essays in sociology, Hans Heinrich Gerth y Charles Wright Mills (eds.), Oxford University Press, New York.

([1921] 1968): Economy and Society, Vol. I, Bedminster Press, New York.

([1895] 2003a): "The nation state and economic policy", en Peter Lassman y Ronald Speirs (eds.): Weber: political writings, Cambridge University Press, Cambridge, pp. 1-28.

([1917] 2003b): "Suffrage and democracy in Germany", en Peter Lassman y Ronald Speirs (eds.): Weber: political writings, Cambridge University Press, Cambridge, pp. 80-129. 
([1919] 2003c): "The profession and vocation of politics", en Peter Lassman y Ronald Speirs (eds.): Weber: political writings, Cambridge University Press, Cambridge, pp. 309-369

Whimster, Sam (1998): "The nation state, the protestant ethic and modernization", en Ralph Schroeder (ed.): Max Weber, democracy and modernization, St. Martin's Press, New York.

Recibido: 25-11-2010

Aceptado: 28-01-2011 